\title{
Stem Cells, I Presume?
}

\author{
Henk S.P. Garritsen \\ Institut für Klinische Transfusionsmedizin, Städtisches Klinikum Braunschweig gGmbH, Germany
}

This issue of Transfusion Medicine and Hemotherapy is focused on cellular therapies involving stem cells. The topics vary from identity of primary cells and cell lines to the current status of the use of cord blood in Germany.

Dittmar et al. [1] address the identity crisis currently becoming visible with the use of available cell lines: $20-30 \%$ of the cell lines in use are not the cell lines we think they are. This hypothesis is recently being supported by a paper of Boonstra et al. [2] and commented on in an editorial by Shoemaker [3]. The authors found that 3 (SEG-1, BIC-1 and SK-GT-5) of the 13 most widely researched esophageal cancer cell lines are contaminated with other malignancies, such as lung and bowel tumor cells, or are misidentified. Even more frightening is the fact that once a cell line is unmasked, still numerous publications are accepted in which these cell lines are used (W. Dirks, personal communication). Several publishers have started to take action in the way that in papers where cell lines are used a verification of the authenticity of the cell line has to be presented before publication. Dittmar et al. [1] introduce us to the state of the art technologies in this area which will be important not only for cell lines but also for the quality control of primary cells after cultivation and manipulation.

Lindner et al. [4] turn our attention to a different 'stem' cell: the mesenchymal stem cell. In their view the definition of mesenchymal stem or stromal cells has some flaws which makes it difficult to compare publications from different sources. They propose a set of criteria for a better definition of mesenchymal stem cells which will certainly be helpful in analyzing this novel cell source.

Freimark et al. [5] presented a review on techniques for the encapsulation of stem cells. Focusing on hematopoietic and mesenchymal stem cells, the prospects and procedures of encapsulating single cells are discussed, and an outlook on their potential clinical use is given.

Schäfer [6] draws our attention from the cultivation of stem cells toward a potential diagnostic use of stem cells. In his overview recently developed labeling and imaging techniques of cells are presented. However, there are still a number of difficulties to overcome before these techniques are available in routine clinical use.

Although one gets the impression that the clinical use of cord blood is going like a wild fire all over the world, culminating in double cord transplantations, in Germany, the clinical use is at present only a smouldering fire. Lauber et al. [7] of the Mannheim Cord Blood Bank informs us about the current status of cord blood transplantation and the exiting new developments in this field which will certainly turn up the heat also in Germany.

All together this issue of Transfusion Medicine and HeMOTHERAPY contains a nice bouquet of stem cell informations, I presume.

\section{References}

1 Dittmar KEJ, Simann M, Zghoul N, Schön O, Meyring W, Hannig H, Macke L, Dirks W, Miller K, Garritsen HSP, Lindenmaier W: Quality of cell products: authenticity, identity, genomic stability and status of differentiation. Transfus Med Hemother 2010;37(2):57-64.

2 Boonstra JJ, van Marion R, Beer DG, Lin L, Chaves P, Ribeiro C, Pereira AD, Roque L, Darnton SJ, Altorki NK, Schrump DS, Klimstra DS, Tang LH, Eshleman JR, Alvarez H, Shimada Y, van Dekken H, Tilanus HW, Dinjens WN: Verification and unmasking of widely used human esophageal adenocarcinoma cell lines. J Natl Cancer Inst 2010;102:271-274.

3 Shoemaker RH: Identification of bona fide esophageal adenocarcinoma cell lines. J Natl Cancer Inst 2010;102:212-213.

4 Lindner et al: Mesenchymal stem or stromal cells: towards a better understanding of their biology? Transfus Med Hemother 2010;37(2):75-83.
5 Freimark D, Pino-Grace P, Pohl S, Weber C, Wallrapp C, Geigle P, Pörtner R, Czermak P: Use of encapsulated stem cells to overcome the bottleneck of cell availability for cell therapy approaches. Transfus Med Hemother 2010;37(2):66-73.

6 Schäfer R: Labeling and imaging of stem cells promises and concerns. Transfus Med Hemother 2010;37(2):85-89.

7 Lauber S, Latta M, Klüter H, Müller-Steinhardt M: The Mannheim Cord Blood Bank: experiences and perspectives for the future. Transfus Med Hemother 2010;37(2):90-97.

\section{KARGER}

Fax +497614520714

Information@Karger.de

www.karger.com (c) 2010 S. Karger GmbH, Freiburg

Accessible online at:

www.karger.com/tmh
Dr. Henk S.P. Garritsen

Institut für Klinische Transfusionsmedizin

Städtisches Klinikum Braunschweig gGmbH

Celler Straße 38, 38114 Braunschweig, Germany

Tel. +49 531595-3675, Fax -3758

h.garritsen@klinikum-braunschweig.de 